\title{
Efforts to Improve Indonesian Language Learning Outcomes Using 4-D Model
}

\author{
Chandra Anugrah Putra \\ Muhammadiyah University of Palangkaraya \\ RTA. Milono Km. 1.5, 73111 \\ Palangkaraya, Indonesia \\ chandra.anugrah@umpalangkaraya.ac.id
}

\begin{abstract}
This research is aimed to (1) find out the students' learning activity in languages Indonesia using learning model 4-D on the students of class IV Primary School 5 Panarung Palangka Raya in academic year 2016/2017, and to (2) improvement of learning outcomes of languages Indonesia using learning model 4-D. This research was Classroom Action Research. The subject in this research whole students at the IVa grade of elementary school, Based on the result of this research shows that: (1) Students' learning activity is improved in languages Indonesia the with to use it model 4-D 41 scores in good criteria (First Cycle) increased to 49 in very good category (Second Cycle). (2) languages Indonesia learning outcomes increased after using the model 4-D, it was seen from the pre-test by the average was 55,21 with classical completeness $39,13 \%$, first cycle with average 67,82 the classical completeness $78 \%$, second cycle with average 76,95 the classical completeness $100 \%$. This was show that successful learning and over the classical completeness value $85 \%$.
\end{abstract}

Keywords-Indonesian language; learning outcomes; 4D model

\section{INTRODUCTION}

The use of learning model is one of learning strategy, to improve the spirit of learners in learning so that learners can be easier to understand the material presented by educators. The same is also required in the Indonesian lesson for material "to describe the place according to the floor plan".

According Basri [1, pp. 34] states that: Based on some opinions above can be concluded that education is the process of guidance and guidance that is done someone continuously to the students to achieve the desired educational goals. Peorwadarminta [1, pp. 250] states that education comes from the Greek, namely paedaggogie which means guidance given to the child. Education is a conscious and planned effort to create an atmosphere of learning and learning process so that learners are actively developing their potential.

One of the learning models used to improve students learning outcomes in Indonesian subjects is by using 4-D learning model (define, design, develop, disseminate). Media is one component that is very important in the learning process because it brings a significant influence in the achievement of learning objectives. In this case the media / tool is useful to cultivate the excitement of learning.
Researchers get problems that is, learners have difficulty when describing the place in accordance with the plan and poured his understanding into the form of writing or writing. Writing skills of learners have not shown maximum results, especially on the aspects of writing, language use, use of spelling and punctuation, support and data / events, and selection of words / diction. Of the 23 students there are 9 students who get the scores of 65 , while the other 14 students have not achieved the predetermined value of completeness, the average score of the learners is 50 .

This research is important because researchers interested and inspired to improve learning outcomes by using 4-D learning model on Indonesian subjects on the subject "to describe the place in accordance with the designated floor plan". In order to foster the spirit, intention, and liveliness of learners in the learning process and can increase learning outcomes of learners in achieving minimum criteria that has been determined.

\section{LITERATURE REVIEW}

Talking about learning and learning is talking about something that never ends since humans exist and thrive on earth until the end of time. Hintzman [2, pp. 65] learning is a change that occurs within an organism, human or animal, caused by experiences that may affect the behavior of the organism. Thus, in the view of Hintzman, the changes generated by the experience can only be said to be learned when it affects the organism. So, it can be concluded that learning is an activity of daily routines that is lifelong learning, in an effort to improve the quality of oneself so that there is a change in both the form of behavior, knowledge, understanding, and emotional in the individual itself.

Good [3, pp. 214] states that grades are symbols (numbers, letters, or words) that illustrate the value of considerations related to the quality of students in achievement during the teaching period. According to Gagne [3, pp. 215] that the observable appearances as a result of learning are called abilities. So, it can be concluded that the results of learning is a picture of the achievement of the quality of self-learners during the learning process.

Learning outcomes are the abilities possessed by learners after they have received the learning experience. Some 
experiences gained by learners include the cognitive, affective and psychomotor aspects. Learning outcomes have an important role in the learning process because it will provide an information to teachers about the progress of learners in an effort to achieve learning objectives. Successful and not a person in learning due to several factors that affect the achievement of learning outcomes is derived from within the people who learn and some are from outside the self.

Bahasa Indonesia is the official language of the Republic of Indonesia Language Unity of Indonesia. Inaugurated its use after the proclamation of Indonesian independence. Anwar [4, p. 13] that "society will not run without communication. Communication in this case (influencing language) is a vital tool for human society ". From the above opinion can be concluded that the Indonesian language is the official language as a means of communication used in the association within society to mirror ourselves as the nation of Indonesia.

Basiran states that the goal of Indonesian learning is communication skills in various communication contexts. A Akhadiah stated that the goal of Indonesian language learning is that students have the ability to speak Indonesian well and correctly and can live Indonesian language and literature in accordance with the situation and objectives of language and level of experience of elementary school students. Based on some opinions above, it can be concluded that the purpose of learning aimed at the students are able to appreciate and also the Indonesian literature and have good and true ability in language.

Sudjana states that the floor plan is a visual medium in graphical form, graphic media is defined as a medium that combines facts and ideas clearly and strongly through a combination of expressions of words and pictures.

As according to Azhar Aryad [5, pp. 46] that the plan is a variety of events or events, objects are poured in the form of pictures, lines of words, symbols and images. So it can be concluded that the floor plan is a visual tool that describes a fact or idea clearly either in the form of events, events or objects that are poured in the form of pictures.

Soekamtodan Winataputra states that the learning model is a conceptual framework that describes a systematic procedure in organizing learning experiences for students to achieve learning objectives and functions as guidelines for instructional designers and teachers in planning and implementing teaching and learning activities.

Soekunto states that the learning model is a conceptual framework that delineates systematic procedures in coordinating learning experiences to achieve certain learning goals and serves as a guide for instructional designers and teachers in planning teaching and learning activities.

Based on the above opinion can be concluded that, the learning model is the framework (guidance) of learning systematically arranged to improve teaching and learning activities to help achieved the learning objectives itself.

The device development model as suggested by Sivasailam Thiagarajan, Dorothy S. Semmel, and Melvyn I. Semmel, [6, p. $189]$ is a 4-D model. This 4-D model consists of 4 development stages, namely define, design, develop, and disseminate, or adapted into a 4-P model, defining, designing, developing, and deploying. Meanwhile, according to Rusdi [9, p. 190] 4-D development model (Four D) is a model of learning device development. So it can be concluded that the 4-D model is a development model, consisting of 4 development stages, define, design, develop, and disseminate, or adapted into a 4-P model, defining, designing, developing, and deploying.

According to Benny A. Pribadi [7, pp. 105] states that "The application of 4-D learning model aims to create a successful learning, which is learning that can help students achieve the desired competence". While AT \& T or America Telephon \& Telegraph [8, pp. 90] states that "4-D model as a prescription in preparing events and activities necessary to provide guidance toward the achievement of certain learning goals". Thus, it can be concluded that the goal of the 4-D model is to create successful learning and learning that can help learners achieve the desired competencies.

\section{METHODOLOGY}

The type of research used in this study is a classroom action research (CAR) with the aim is to improve the ability of writing and learning outcomes Indonesian language. According to Hopkins [9, pp. 8] states that CAR is a form of reflection, conducted by actors to improve the rational determination of its actions in carrying out its duties and deepening understanding of conditions in the practice of learning. Meanwhile, according to McNiff [10, pp. 8] states that "CAR is a form of reflection research conducted by the teacher himself whose results can be utilized as a tool for the development of teaching skills. So, it can be concluded that CAR is a form of reflection study by actors that is by the teachers themselves to improve learning outcomes of learners in the learning process.

The presence of researchers in this research is as planner, executor of action, observer, reflector and reporter of research result. The researcher also acts as the subject of the action giver, the researcher as the teacher or the model teacher in charge, who design the implementation of the teaching as well as convey the teaching materials during the learning process, besides the researchers also collect and analyze the data as well as reporting research results.

In this case the researchers collaborate with one teacher of Indonesian language and one peer who served as observer or observer in charge of collecting data learning process. The process of this research is in order to apply the 4-D learning model on Indonesian Language subjects with the aim of improving learners' learning outcomes.

Pre-cycle is done to give pretest to learners about the material to describe the place in accordance with the determined plan and obtain the data of the learners to be used as a reference in planning the action cycle I. After knowing the ability of the learners then the data pretest results are analyzed to acknowledge data results of participant students who have not understood the material to describe the place in accordance with the designated floor plan. Students who still score below the minimum completeness criteria will then be used as research samples and continue on cycle I, if the first cycle has 
not been successful then continued on cycle II, and so on until the cycle $\mathrm{N}$.

The design used in this study is a classroom action research design implemented through I cycle. According Kemmis and McTaggart [14, pp. 30] states that "each cycle through four stages, namely (1) Planning, (2) Implementation, (3) Observation, and (4) Reflection".

The main action taken is to develop a lesson plan, organize the activities of learners and make research instruments in the form of questions. But the first is the initial test in comparing the success of the action through learning activities.

In carrying out the action steps are carried out as follows: (1) implement the learning process by giving the matter of writing essays without using the media plan for the reason of research want to know the extent of knowledge writing essay according to ideas, opinions, thoughts, develop the title, a sentence because the researcher assumes that the learners begin to be taught to write essays (2) make observations about the activities of learners during the learning process takes place (3) give the final test.

Observation and observation is done by observing and recording all activities of learners that seem to take place during the learning process. The purpose of the observation is done as a refinement and refining material for subsequent action.

On the first round, and second, the initial test is done. In the first round of research to reflect with colleagues, examine the things that become problems in the students in writing essays with learning materials Indonesian language subject discussed the place according to the plan. If cycle I has not reached the success criteria of action then proceed to cycle II.

Instrument of data collection in this research is test instrument of learners in describing the place according to the plan using the layout media that has been determined the topic, and observed by observer team after the end of teaching and learning process.

Data processing stage is an important stage in a study, because this stage researchers can formulate the results of research and data collected from each activity undertaken in the cycle analyzed descriptively by using percentage to see trends that occur in learning.

\section{RESULTS AND DISCUSSION}

The average value and the value of the learning result obtained the results of the initial test students obtained an average score of 55.21 and $39.13 \%$ complete learning included in the criteria is very less achieved. The average score obtained by learners of 55.21 still does not meet the criteria of completeness of at least 65 and the value of learning achievement of $39.13 \%$ is also still far from the classical completeness criteria $85 \%$. So that in the initial test in the determination of the level of achievement of learning outcomes have not fulfilled the study mastery requirements.
Learning outcomes of learners since the initial test to apply the 4-D model on the cycle I and cycle II can be seen in the following table:

TABLE I. LEARNING OUTCOMES RECAPITULATION

\begin{tabular}{|c|c|c|c|c|}
\hline No & Data & $\begin{array}{c}\text { Average } \\
\text { Score }\end{array}$ & Max Score & $\begin{array}{c}\text { Percentage of } \\
\text { Classical } \\
\text { Exhaustiveness }\end{array}$ \\
\hline 1 & $\begin{array}{c}\text { Pre- } \\
\text { Cycle }\end{array}$ & 55,21 & 100 & $39,13 \%$ \\
\hline 2 & Cycle I & 67,82 & 100 & $78 \%$ \\
\hline 3 & Cycle II & 76,95 & 100 & $100 \%$ \\
\hline
\end{tabular}

The increase in value graphs from Pre-Cycle Cycles I, II are illustrated below:

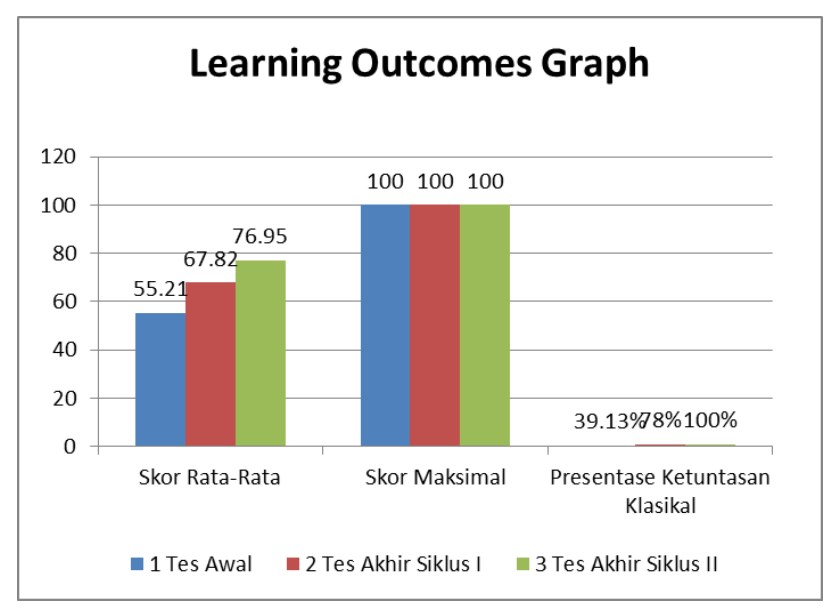

Fig. 1. Learning Outcome Graph

Based on the tables and graphs of students learning outcomes above can be seen that in the initial data the average score of learners only get the value of 55.21, this value is still below from the determined criteria that is determined 65 . The result of mastery of learners was only get $39.13 \%$, this value is very far from the value of classical defined criteria that is determined is $85 \%$. Then in the first cycle the average value of students increased to 67.82 with the result of classical learning learners classical completeness $78 \%$, this value almost reaches the classical completeness criteria determined. So it must optimize again the learning process in cycle II which gets an average score of 76.95 with the result of classical completeness learners $100 \%$ learners. It has reached the indicator of the success of the research that has been determined that the learning outcomes of learners achieve $\mathrm{KKM} \geq 65$ with $85 \%$ classical completeness.

Based on the observation and the data obtained in cycle I, the students' activity obtained an average score of 41 with good enough criteria. In cycle II, the average score is 49 with good criteria. The results have reached the indicator of the success of learning activities that have been determined learner $\geq 45$.It 
shows that students of class IVA Primary School 5 Panarung Palangka Raya active at the time of learning Indonesian by applying the 4-D model then the hypothesis of action is tested truth.

Based on test results and data obtained preliminary test data, learning outcomes learners gain an average value of 55.21 (under $\mathrm{KKM} \geq 65$ ) with $39.13 \%$ classical completeness. In the first cycle of learning outcomes learners get an average score of 67.82 with $78 \%$ classical completeness. In the second cycle, the learner achieves an average score of 76.95 , with $100 \%$ classical completeness. It has reached the indicator of the success of the research that has been determined that the learning outcomes of learners achieve minimum criteria $\geq 65$ with $85 \%$ classical completeness. This shows that there is an increase of learning result of Indonesian class IV student by applying 4-D model in learning, then the hypothesis of action is tested its truth.

Learning English results of learners. It can be concluded that the implementation of 4-D model in the learning process of Indonesian language can improve the aspects of the activities of learners during the learning process takes place and can improve learning outcomes of learners. Enhancement of learners' ability and understanding is seen from two learning result of cycle I and cycle II. The 4-D model can be applied to Indonesian language learning to enhance the creativity of individual learners.

Based on the analysis of data conducted on the activities of learners can be obtained the results of the activities of learners in each cycle. In the first cycle, the learner activity scored an average of 41 on the criteria (Good). Given the criteria quite well in cycle I was because students are able to work together and communicate in the learning process. In the second cycle of activity learners get an average score of 49 with good criteria. It has reached the completeness indicator of learning activities of students that have been determined $\geq 45$, with $85 \%$ classical completeness. Given the criteria both in the second cycle of motivation to learners in the learning process that looks more active in the interaction, and able to answer questions given teachers. This shows that learners are more active during Indonesian language learning by applying the 4D model.

Based on the analysis of data conducted on student outcomes, it can be concluded and can be obtained learners learning outcomes from the initial test, the final test cycle I and the end test of cycle II. In the preliminary test, students' learning outcomes scored an average of 55.21 with $39.13 \%$ classical completeness. In the first cycle, students get the average score of 67.82 , with $78 \%$ classical completeness. In the second cycle increased learning outcomes of students get an average score of 76.93 with $100 \%$ classical completeness.

\section{CONCLUSION}

Based on the results of research that has been done on learning Indonesian on the subject matter to describe the place according to the plan using the 4-D learning model at primary school 5 Panarung Palangka Raya Lesson Year 2016/2017 can be drawn conclusion as follows:

- Student learning activities in Indonesian language learning using 4-D learning model, in students of class IVA primary school - 5 Panarung Palangka Raya, the data in cycle I in score 41 with the criteria (Good), while the second cycle increased to 49 with the criteria (Good) the score has met the activity score of learners in learning $\geq 45$.

- There is an increase of learning result of Indonesian language using 4-D learning model on students of class IVA primary school - 5 Panarung Palangka Raya initial data obtained by average 55,21 with 39,13\% classical completeness, while at cycle I 67,82 with mastery classical 78\%, and in cycle II the average value of 76.95 with $100 \%$ classical completeness.

\section{REFERENCES}

[1] B. Hasan, Landasan Pendidikan [Education's Foundation]. Bandung: CV Pustaka Setia, 2013.

[2] H. Suyono, Belajar dan Pembelajaran [Learn and Learning]. Bandung: PT Remaja Rosdakarya, 2014.

[3] Sukardi, Evaluasi Pendidikan [Education Evaluation]. Jakarta: PT Bumi Aksara, 2010.

[4] D. Kusumaningsih, S. W. Saptomo, Suparmin, T. Sudiatmi, and B. Triyanto, Terampil Berbahasa Indonesia [Skillful using Indonesian Language]. Yogyakarta: C.V Andi Offset, 2013.

[5] A. Azhar, Media Pembelajaran [Learning Medium]. Jakarta: Raja Grafindo, 2005.

[6] Trianto, Mendesain Model Pembelajaran Inovatif-Progresif [Designing Innovative-Progressive Learning Method]. Jakarta: Kencana Preneda Media Grup, 2012.

[7] Suparman, Desain Instruksional Modern [Modern Instructional Design]. Jakarta: Erlangga, 2012.

[8] Rusman, Model-Model Pembelajaran: Seri Manajemen Sekolah Bermutu [Learning Models: Excellent School Management Series]. Jakarta: Raja Grafindo Persada, 2012.

[9] M. Masnur, Melaksanakan PTK itu Mudah [Conducting PTK is Easy]. Jakarta: Bumi Aksara, 2013

[10] W. Kusumah and D. Dwitagama, Mengenal Penelitian Tindakan Kelas [Recognizing Research of Class Act]. Jakarta: PT Indeks, 2012.

[11] Kasbollah, Penelitian Tindakan Kelas [Class Act Research]. Depdikbud Dirjen Dikti Proyek PGSD, 2009. 